\title{
Tayside's contribution to the early development of cardiology
}

G Lowe

Retired Dermatologist and Honorary Curator of Tayside Medical History Museum, Dundee, Scotland, UK

\begin{abstract}
This paper gives a brief account of how doctors who were either native to or actively working in Tayside helped to shape the early development of cardiology. It exemplifies how important contributions to the understanding and practice of medicine can be made by an exceptional individual or an inspired team, no matter how unlikely the initial setting for their work might appear. The remarkable role that Sir James Mackenzie played in the understanding and fostering of this speciality in its infancy is outlined. The paper also describes the transformation of Dundee Royal Infirmary's meagre facilities after the Second World War into a dynamic centre of excellence in cardiology services in the 1960s, becoming in effect a prototype for the highly acclaimed 'embedding' of clinical care, teaching and research at the new Ninewells Hospital and Medical School in Dundee.
\end{abstract}

KEYWORDS Cardiology, Tayside, Sir James Mackenzie, Dundee Royal Infirmary

DECLARATIONS OF INTERESTS Dr Lowe is the son of Dr (later Professor) Kenneth Gordon Lowe, who is described in this article. Sections from this article have previously been published on the Tayside Medical History Museum's website.
Correspondence to G Lowe, Greengaites, 3 Glamis Drive, Dundee DD2 IQG Scotland, UK

tel. $+44(0) / 38263004$ I e-mail grahamlowe@nhs.net
Tayside Medical History Museum is fortunate to have in its collection a wooden stethoscope that at one time belonged to the inventor of that instrument. René Laënnec had given this particular stethoscope to William Sharpey, a native of Arbroath often referred to as the 'father of modern physiology' in Britain.' Sharpey later handed it on to his half-brother James Arrott, who in 1837 set up the first institution in Dundee for studying diseases of the chest. Historic items such as this, complemented by explanatory text, vividly illustrate medical advances and changing patterns of care over time.This paper outlines how the care of patients with heart disease evolved in Tayside up to the opening of Ninewells Hospital and Medical School in 1974, and details the most notable contributions to cardiology made either within the region, or by its natives elsewhere. Images relating to their work can be seen on the Museum's website:

www.dundee.ac.uk/museum/medical.htm

\section{SIR JAMES MACKENZIE}

This account must start with Sir James Mackenzie (1853-1925), who was the key figure in shaping British cardiology. ${ }^{2}$ Born at Pictstonhill Farm on the outskirts of Scone, in whose ancient Abbey Scotland's kings had been crowned upon the Stone of Destiny, Mackenzie was destined for greatness as a clinical investigator. At an early stage of his busy general practice in the mill town of Burnley he realised there was a lack of understanding of the cause and significance of the symptoms and signs that he encountered in his everyday work. This prompted an investigation through prolonged and careful clinical observation of large numbers of patients and repeated analysis of his records. His main interests from an early stage were cardiovascular disease in general, and cardiac failure in pregnant women in particular. To aid him in the analysis of heartbeat irregularities he made pulsation recordings, initially with a modified Dudgeon sphygmograph that allowed him to record venous pulsations simultaneously with arterial, followed later by his own invention, the multichannel ink-writing polygraph. In 1902, after 28 years of single-handed pain-staking observations and recordings, he published the results in The Study of the Pulse. ${ }^{3}$ This book was pivotal in the development of cardiology and by this time he had undoubtedly become the world clinical authority on the heart. ${ }^{4}$ Impressed by the depth of Mackenzie's work, many distinguished medical figures from around the world, including the celebrated Canadian physician William Osler and Dutch-born Viennese cardiologist Karel Wenckebach, made the journey to his out-of-the-way Lancashire home.

Mackenzie had not at that time received the acclaim in his own country that was being afforded him from overseas, so he moved to London in 1907 in order to expound more fully on his radical views. He published his definitive work The Heart ${ }^{5}$ the following year, and in 1913 was appointed Physician-in-Charge of the first cardiac department in the UK at The London Hospital. Here he gathered together and inspired men such as Thomas Lewis and John Parkinson, both of whom were later knighted. During World War I, he and Lewis set up a study at Mount Vernon Hospital in Hampstead on the 
so-called 'soldiers' heart', where assessment concentrated on functional efficiency of the heart rather than the presence of supposed or dubious anatomical lesions, a major shift in assumptions. This led to a re-definition of the disorder as 'effort syndrome' and allowed thousands of men to be declared fit for active service. Mackenzie introduced objectivity and measurement to the understanding of cardiac irregularities, in particular showing the harmless nature of extrasystoles and sinus arrhythmia, and rationalising digitalis therapy, major developments in his field. He is perhaps best known for his recording of the disappearance of the ' $a$ ' wave of atrial contraction from the jugular pulse and the presystolic murmur of mitral stenosis with the onset of what he recognised as 'paralysis of the auricle', later to be identified as atrial fibrillation. He continues to be recognised for this development; in 1998, the Royal College of Physicians of Edinburgh organised the Sir James Mackenzie Consensus Conference on Atrial Fibrillation at St Andrews. (Supplement available at: http://www.rcpe. ac.uk/journal/supplements/supplement-6.pdf.

Despite his success and the honours he earned, including a knighthood and election as Fellow of the Royal Society (FRS), Mackenzie gave up his lucrative practice in London in order to return to his general practice roots, where he felt that the significance of early signs and symptoms of disease could best be studied by long-term follow-up of patients. He relocated to St Andrews in 1918 to found the innovative Institute for Clinical Research in a handsome Victorian villa on the Scores, where the general practioners (GPs) of the town could work collaboratively under Mackenzie's leadership. Two years later he was appointed Physician to the King in Scotland. The Institute can be regarded as the first step in the establishment of general practice as a specialty with a unique clinical and research role and its founder is rightly revered as the father of research in general practice. ${ }^{6}$ Although his Institute closed its doors in 1944 , it left behind a group of records which are still used to this day. ${ }^{7}$

Mackenzie himself had suffered from cardiac pain since 1908, and indeed was 'Case 28' in his own book Angina Pectoris, ${ }^{8}$ published in 1923. He died shortly after developing severe cardiac pain while at a Burns Supper in London in 1925. In accordance with his express wish, his heart was removed by his loyal assistant John Parkinson and sent to David Waterston, the Professor of Anatomy at St Andrews University, who with the help of DF Cappell, Professor of Pathology in Dundee, wrote up the morphological features in the British Heart Journal. ${ }^{9}$ To this day, Sir James's preserved heart is on permanent display at St Andrews University's Medical School, where it serves as an inspirational icon for medical students.

\section{THE BEGINNINGS OF CARDIOLOGY IN DUNDEE}

Mackenzie recognised the value of the electrocardiogram (ECG) machine but was concerned that doctors would get too fond of instruments and allow their clinical senses to atrophy. ${ }^{10}$ Despite these misgivings the first ECG duly arrived at Dundee Royal Infirmary (DRI) in 1924, the year before he died. The $£ 350$ purchase price was met by St Andrews University, with the Infirmary responsible for the running costs. This somewhat cumbersome machine (Figure I), which according to the local press was acquired 'to probe the secrets of the heart'," was placed under the charge of Dr William Malcolm (187I-1936). A native of Blairgowrie in Perthshire, Malcolm was both a GP and Assistant Physician at DRI and also served as cardiologist and medical specialist to the Ministry of Pensions. He published articles in the British Medical Journal on 'Right Branch Bundle Block [sic]' in 192712 and 'The Electrocardiograph and Alternating Current Interference' in 1931.13 In his BMJ obituary he was described as 'Electrocardiographer'; the directors of the hospital paid tribute to the care, precision and devotion to his pioneering cardiac work. It is evident that he was a man of talent and wide accomplishment; he could be considered as the progenitor of cardiology in Dundee's medical school. ${ }^{14}$

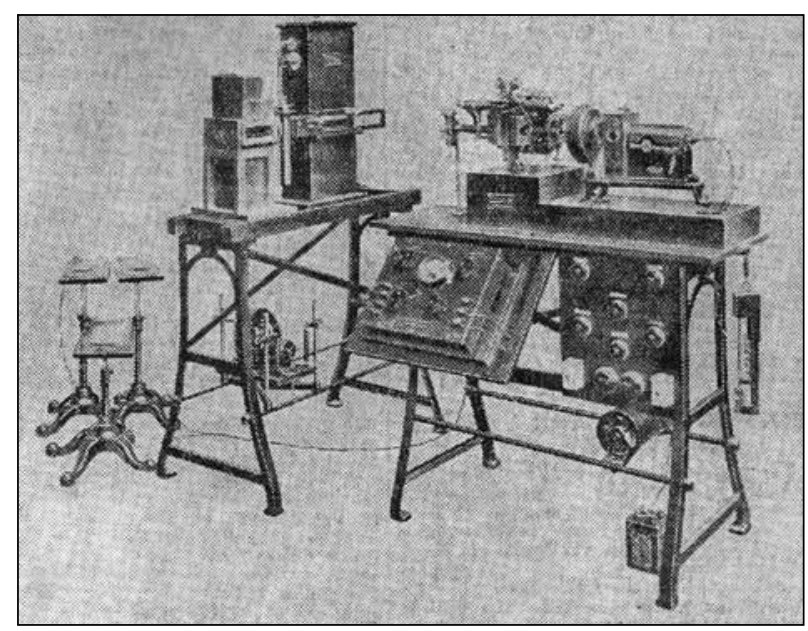

FIGURE I The first ECG machine in Dundee. (Dundee Advertiser 1924 ( ) The Courier, D C Thomson \& Co Ltd)

Malcolm was succeeded as electrocardiographer by $\mathrm{Dr}$ Alexander Macklin (1889-1967) who had settled in Dundee in 1925 as a GP, with anaesthetic duties at DRI. Macklin was a man of many parts. After his great adventure as a surgeon on the 19/4-7 Imperial TransAntarctic Expedition with Ernest Shackleton (where all were miraculously saved from Elephant Island), he returned to the Antarctic with Shackleton in 1921 where he had the grim task of confirming at postmortem examination his leader's fatal coronary heart disease. Army service in World War I gained him an MD based 
on his work in the North Russian Winter Campaign. He was also the recipient of the Polar Medal, OBE, Military Cross and the Imperial Order of St Stanislaus. ${ }^{15}$ In addition, Mount Macklin in South Georgia is named after him, an unusual honour for a doctor. On his return to DRI after service in World War II, he was disappointed to find his department 'in chaos' and his anaesthetic records scattered. He resigned his post to take charge of the Student Health Service at Aberdeen University, and Dr John Gordon Clark was appointed to fill the vacancy at DRI.

Macklin taught Kenneth Gordon Lowe (1917-2010) the rudiments of clinical examination. Lowe remembered being interviewed as a medical student for an ongoing study at Mackenzie's Research Institute in 1936, and he later returned to his alma mater after the war. Before World War II, medicine was taught at DRI by Professor Adam Patrick, assisted by GPs with hospital attachments. Patrick was largely dependent on private practice for his income, and had no personal office of his own. The academic department of medicine was little more than wards and outpatient rooms. Lowe remembered that students of the time were very familiar with Sydenham's chorea, rheumatic heart disease and syphilitic aortitis and knew the importance of hypertension, but coronary disease was uncommon. Treatments for heart disease included bed rest, Southey's tubes for peripheral oedema, morphine for left ventricular failure, pheno-barbitone for high blood pressure, and tablets of digitalis leaf and mercurial diuretics. 'Myocardial degeneration' was a frequent entry on death certificates, showing that understanding of heart disease was vague at that time..$^{14}$

\section{EXPONENTIAL GROWTH AFTER WORLD WAR II}

All this was to change dramatically with the induction in I95I of the already distinguished lan Hill (1904-1982) and Donald Douglas $(1911-1993)$ as the first full-time Professors of Medicine and Surgery respectively, at the University of St Andrews. These driving personalities collaborated closely in the care of cardiac patients and went on to transform their departments into dynamic modern academic units achieving national and international recognition. Both men had been awarded military honours during World War II and were later knighted. They became the first ever Presidents of their respective Edinburgh Colleges from outwith the capital, and held appointments as Physician and Surgeon to the Queen in Scotland (as did Lowe at a later date). It was to be a golden period, dominated by basic and clinical research, with Dundee at the cutting edge of advances in cardiology.

\section{A professorial medical team created}

In his early postgraduate career, lan Hill was heavily influenced by the distinguished Edinburgh physicians $\mathrm{Dr}$ R Gilchrist and Professor WT Ritchie. The latter had published a monograph on auricular flutter in 1914 , and directed Hill's attention to Craib's studies on the fundamental physiological basis of electrocardiography, which challenged concepts long taught by physiologists. Frank $\mathrm{N}$ Wilson, one of the three founding fathers of electrocardiography (along with Willem Einthoven and Sir Thomas Lewis), had independently published similar studies and reached similar conclusions. As a recipient of a Rockefeller Travelling Fellowship in the 1930s and at Ritchie's instigation, Hill went to Wilson's famous 'Heart Station' at Ann Arbor in Michigan where he did important work on electrocardiography. In 1950 he explained the new unipolar $V$ leads to UK doctors in a highly influential article in the Lancet. ${ }^{16}$ Hill's first research priority on arriving in Dundee was to set up a cardiac diagnostic laboratory, in part to support the need to develop cardiac surgery. Despite being the third holder of the Chair of Medicine, his own office and rooms for his secretarial and medical staff had to be newly created within a mansard roof of the Medical School.

In 1929, Werner Forsmann performed the first cardiac catheterisation (on himself) in Germany. This technique was refined more formally in the 1940s by Cournand and Richards at Columbia University Medical Center in New York. In the UK, John McMichael and Peter SharpeySchafer pioneered cardiac catheter studies at the Postgraduate Medical School at Hammersmith Hospital in London, where on his return from the Second World War Lowe acquired expertise in the technique when measuring renal blood flow and in the diagnosis of congenital heart disease. Lowe later teamed up with cardiologist John Goodwin and radiologist Robert Steiner to introduce angiocardiography as a supplement to the cardiac catheter service, studying the pulmonary vasculature in patients with mitral stenosis and varying degrees of pulmonary hypertension. ${ }^{17} \mathrm{He}$ was appointed Senior Lecturer in Medicine at the University of St Andrews in 1952, and was able to bring these and other research techniques to Dundee. In Hill's cardiac laboratory, accommodated in a cramped turret room beside Ward 8 at DRI, Lowe was one of the first in Scotland to use right heart catheterisation in the preoperative assessment of patients with rheumatic and congenital heart disease (Figure 2).

With the appointment in 1954 of Dr Donald EmslieSmith (b 1922) as cardiac registrar followed soon after by that of Dr Hamish Watson (1923-200I), the Dundee unit's research interest focused initially on intracardiac electrocardiography (IEG) using electrode-tipped catheters. The patterns in the normal heart, right ventricular hypertrophy, bundle branch block and ventricular preexcitation were studied, and simultaneous recording of the IEG and pressure pulse during catheterisation of patients with pulmonary stenosis helped in identifying the site of the obstruction in the right ventricular outflow tract. In a personal reflection on 50 years of the British Heart Journal in $1989,{ }^{18}$ Howard Burchell from the Mayo clinic nominated 


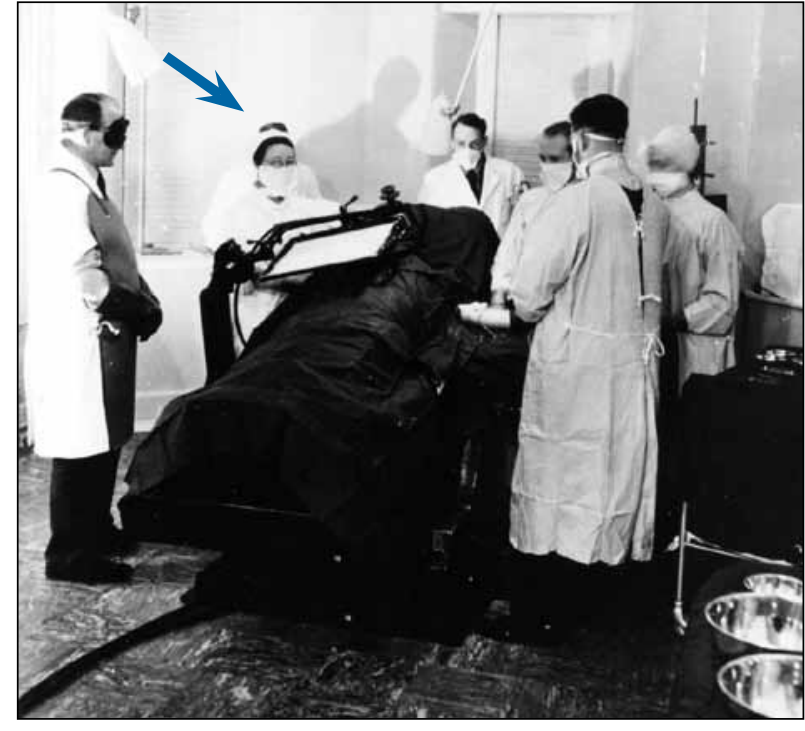

FIGURE 2 Dr KG Lowe (centre) performing an early cardiac catheterisation at Dundee Royal Infirmary. Dr C Pickard from radiology is at far left. Professor Hill is just seen (blue arrow) standing behind the nurse second left. (Courtesy of Tayside Medical History Museum, University of Dundee Museum Services)

Emslie-Smith's 1955 paper on 'The Intracardiac Electrogram as an Aid in Cardiac Catheterisation'19 as one of the three landmark papers from the second decade of the Journal.

In 1955, Emslie-Smith spent a year in Melbourne with a Travelling Fellowship, where he studied the ECG pattern in experimental hypothermia. He elucidated the whole electrocardiographic syndrome of hypothermia in animals and man, and named the conspicuous extra deflection the 'J wave'. ${ }^{20}$ On his return to Dundee, when routinely reporting ECGs at Maryfield Hospital, he recognised cases with characteristic ECG patterns of hypothermia, and was able, by recording rectal temperatures with a long laboratory thermometer in acute admissions, to clarify the clinical picture of accidental hypothermia and emphasise its importance in the community ${ }^{21}$ (at that time traditional clinical thermometers were unable to detect critical hypothermia). He was the first to show that elderly people in the UK could become dangerously hypothermic in their own homes; further work on this subject with Dr Derek MacLean led to a monograph, ${ }^{22}$ invitations to meetings in the UK and overseas, and an advisory role in the development of low reading thermometers.

Having been invited to work at the Hammersmith Hospital where he was Sir John McMichael's Senior Registrar from 1958-6I, Emslie-Smith acquired the left heart catheterisation technique which, with the assistance of the radiologist George Howie, he subsequently introduced in Dundee. He was also awarded a Lown cardioverter by the British Heart Foundation on a research grant, which was soon used frequently in the routine treatment of patients with atrial fibrillation.
Hamish Watson's interest in paediatric cardiology stemmed from the tragic death of his only son from congenital heart disease, and culminated in his editing a standard textbook on heart disease in children, and his founding of and election as the first President of the European Association of Paediatric Cardiologists in 1963. At its 1967 meeting in Rome, Hamish addressed the Pope on behalf of the Association on some of the ethical problems related to congenital heart disease. He pioneered the use of selective cine-angiocardiography with image intensification in children with congenital heart disease with Dr Cecil Pickard from the Department of Radiology, and was the first in the UK to perform atrial septostomy as a life-saving palliative procedure in babies born with transposition of the great arteries. ${ }^{23}$

The most exciting intracardiac work for Hill's team was the search for evidence of conduction along the Bundle of His. This was eventually found and recorded in a teenage girl with Ebstein's anomaly of the tricuspid valve. Publication of the findings in the American Heart Journal in $1967^{24}$ was later cited by Science as one of the most influential scientific reports in a review of some four thousand articles on important cardiovascular and pulmonary subjects, ${ }^{25}$ and led to an invitation to Emslie-Smith from the distinguished American cardiologist Hans Hecht to address an international symposium in Chicago. With more sophisticated equipment available, a flurry of research activity on 'His Bundle recording' quickly followed in America, and led in time to ablative therapy of arrhythmias.

Spatial vectorcardiography was a further area of interest from 1966-75 after Emslie-Smith had acquired the technique in Melbourne. Studies on myocardial infarction, arrhythmias and posture led to several publications, two PhD theses and a number of lecture invitations. Emslie-Smith and Lowe also presented this topic in Sir John McMichael's 1968 Festschrift.

Professor Hill's team spent much of their time teaching. Regular Easter postgraduate cardiology courses proved very popular, with many of the delegates attending from overseas (Figure 3).A number of symposia with cardiology topics were also arranged, attracting distinguished national and international figures. Dundee Medical School's reputation as a cardiac centre of distinction was growing, and in 1963 Professor Hill was able for the first time to attract the elite Association of Physicians of Great Britain and Ireland and the British Cardiac Society (now much enlarged and renamed the British Cardiovascular Society) to Tayside.

\section{Cardiac surgery}

Cardiac surgery was pioneered in Dundee by the technically gifted general surgeon Frank Brown, who performed cardio-omentopexy for angina pectoris in the late 1930s and commenced ligation treatment of patent ductus arteriosus in 1945. Donald Douglas's professorial appointment in $195 \mathrm{I}$ led to the Dundee 


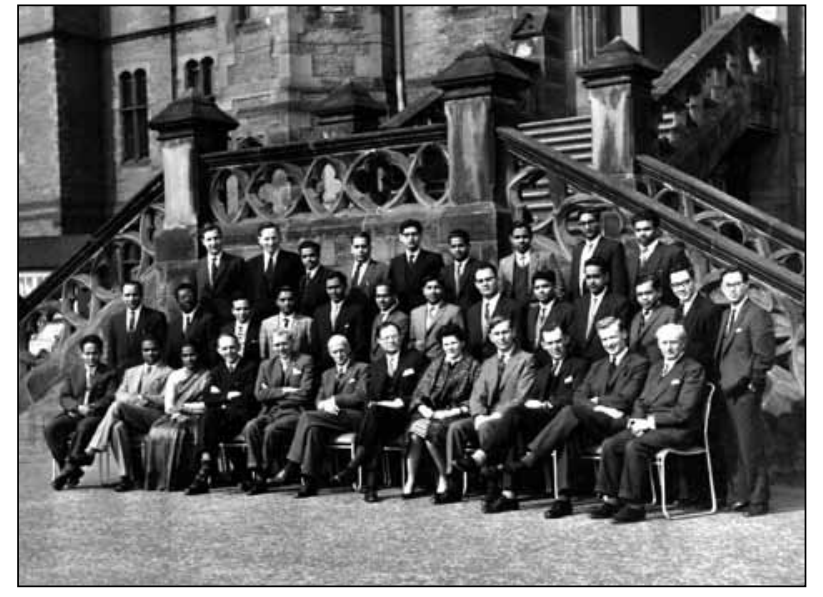

FIGURE 3 Cardiology course participants, Dundee Royal Infirmary, March 1962: KG Lowe, IGW Hill, D Emslie-Smith and $\mathrm{HWatson}$ are seated respectively fourth, sixth, ninth and tenth from the left. Dr RM Marquis, Chief of Cardiology at Edinburgh Royal Infirmary from 1964-78 is seated seventh from left. Author's private collection. Original taken by Norman Brown and Co, Dundee.

surgical unit becoming a recognised centre of clinical excellence in the field of cardiovascular surgery. Born and educated at St Andrews, Douglas was the first British surgeon to do research work at the Mayo Clinic Research Laboratory in Minnesota, and a happy and productive association with Sir James Learmonth in Edinburgh after the war was to stimulate his interest in what was then the infant specialty of vascular surgery.

At DRI, Douglas began performing closed mitral valvotomies in 1952, and with the development of the Melrose pump-oxygenator, open heart surgery for valve replacement and congenital heart disease was regularly performed in the 1960s. In 1965, by which time 401 operations had been performed for rheumatic heart disease of the mitral and aortic valves, Douglas and his surgical colleague William $F$ Walker reported their experience of 25I operations for congenital heart disease. ${ }^{26}$ The noted American cardiac surgeons Michael De Bakey and John Kirklin developed close ties with Douglas' team, and both performed operations at DRI. In time, dwindling numbers of suitable patients and the need to centralise expertise for more complex recurrent cases requiring longer pump times led to open heart surgery ceasing in Dundee, although mitral valvotomies continued until shortly before Ninewells Hospital opened in 1974. Walker went on to become an international figure in the field of peripheral vascular disease. He established, with DrVance Spence, one of the first vascular laboratories in the UK, and was elected President of the Association of Surgeons of Great Britain and Ireland in 1984.

\section{Cardiac arrest reversal}

Acid-base studies were a research interest in Dundee in the 1960s, with William Walker and Dr Gemmell Morgan publishing papers on the Dundee experience in acid- base monitoring and biochemical response to open heart surgery. Mr John S Stewart and Dr Bill Stewart reported the heroic resuscitation of a young man with cardiac arrest complicating hyperkalaemia where the surgeon performed open cardiac massage for two and a half hours; the important learning point was that it was not until the patient's acidosis was corrected by intravenous sodium bicarbonate that satisfactory cardiac action was secured. ${ }^{27}$ Dr Stuart McGowan and Bill Stewart (with the help of the Regional Physics Department) designed and built a series of early cardiac arrest trolleys ${ }^{28}$ and established the DRI cardiac arrest service, which eventually became a commitment of the duty resident anaesthetist.

\section{CONCLUSION}

This paper covers a century of cardiac research activity, which all stemmed from routine clinical work. Despite the minimal facilities available in Dundee Royal Infirmary after the Second World War, published results increased exponentially with time, and the department's fame grew. The integrated clinical care, teaching and research model that was practised in cardiology at the old infirmary successfully spread to all departments at the new Ninewells Hospital and Medical School, where it became known as 'embedding'. The accumulated achievements of those described in this account seem commendable for a relatively small Scottish region with a population of less than half a million.

\section{Acknowledgements}

I am indebted to Professor Stuart Pringle who originally asked me to research his department's predecessors and write a short account for posterity, and to my late father Kenneth Gordon Lowe, Donald Emslie-Smith, Bill Stewart and Mike Lyall for their support and help with bringing it to fruition.

\section{REFERENCES}

I Taylor DW. The life and teaching of William Sharpey (I802-I880) 'Father of Modern Physiology' in Britain. Med Hist 1971; 15:12653; 24I-59.

2 Krikler DM.The roots of modern British cardiology. Br Heart J 1989; 62:230-4. http://dx.doi.org/I0.1 I36/hrt.62.3.230

3 Mackenzie J. The study of the pulse, arterial, venous, and hepatic, and of the movements of the heart. Edinburgh:Young J Pentland; 1902.

4 McMichael J. A transition in cardiology: the Mackenzie Lewis era. The Harveian Oration of 1975. London: Royal College of Physicians; 1976. p.4.

5 Mackenzie J. Diseases of the heart. London: Henry Frowde, Hodder \& Stoughton; 1908.

6 MacNaughton J.The St Andrews Institute for Clinical Research:An early experiment in collaboration. Med Hist 2002; 46:549-68.

7 Professor Cathy Jackson personal communication $201 \mathrm{I}$.

8 Mackenzie J. Angina pectoris. London: Henry Frownde, Hodder \& Stoughton; 1923.

9 Waterston D, Orr J, Cappell DF. Sir James Mackenzie's heart. Br Heart J 1939; I:237-48. http://dx.doi.org/ I0.I I36/hrt. I.3.237

10 Mair A. Sir James Mackenzie MD General Practitioner 1853-1925. Edinburgh \& London: Churchill Livingstone; 1973. p. 261.

II Dundee Advertiser, 10 June 1924. 
12 Malcolm WS. Right branch bundle block. BM] 1927; 1:372-3. http:// dx.doi.org/l0.1 I36/bmj.I.345I.372

13 Lethlean NG, Malcolm WS.The electrocardiograph and alternating current interference. BMJ 1931; 2:1 195. http://dx.doi.org//0.1/36/ bmj.2.3703.1195

14 Professor KG Lowe personal communication 2009.

I5 Levack ID, McGowan SW. Alexander Hepburne Macklin: physician, polar explorer, and pioneer. BMJ 1993; 307:1597-9. http://dx.doi. org/I 0.1 I36/bmj.307.69/9.1597

16 Hill IG. Multiple-lead electrocardiograms. Lancet 1950; I (66 I3):9859I; I (66 I4): I027-33.

17 Goodwin JF, Steiner RE, Lowe KG. The pulmonary arteries in mitral stenosis demonstrated by angiocardiography. J Fac Radiol 1952; 4:21. http://dx.doi.org//0.1016/S0368-2242(52)80038-7

18 Burchell HB. Golden Anniversary of the 'British Heart Journal' BMJ 1989; 298:70. http://dx.doi.org//0.1 /36/bmj.298.6666.70

19 Emslie-Smith D. The intracardiac electrogram as an aid in cardiac catheterisation. Br Heart J 1955; 17:2 19-24. http://dx.doi.org//0.I I36/ hrt.17.2.219

20 Emslie-Smith D, Sladden GE, Stirling GR. The significance of changes in the electrocardiogram in hypothermia. Br Heart J 1959; 21:343-51. http://dx.doi.org//0.1136/hrt.21.3.343
2I Emslie-Smith D. Accidental hypothermia: a common condition with a pathognomonic electrocardiogram. Lancet 1958; 2:492-5. http://dx.doi.org/I0.1016/S0|40-6736(58)9/283-2

22 MacLean D, Emslie-Smith D. Accidental Hypothermia. Oxford: Blackwell Scientific Publications; 1977.

23 Watson H, Rashkind WJ. Creation of atrial septal defects by balloon catheter in babies with transposition of the great arteries. Lancet 1967; 289:403-5. http://dx.doi.org/I0.1016/S0I40-6736(67)9II72-5

24 Watson H, Emslie-Smith D, Lowe KG. The intracardiac electrocardiogram of human atrioventricular conducting tissue. Am Heart J 1967; 74:66-70. http://dx.doi.org//0.1016/00028703(67)9004I-5

25 Comroe JH Jr, Dripps RD. Scientific basis for the support of biomedical science. Science 1976; 192:105-II. http://dx.doi. org/I0.1 I 26/science.769/6I

26 Douglas DM, Walker WF, Breckenridge IM et al. Congenital heart disease; a review of some surgical problems. Scott Med J 1965; 10:143-58.

27 Stewart JSS, Stewart WK, Gillies HG. Cardiac arrest and acidosis. Lancet 1962; 2:964-7. http://dx.doi.org/I0.1016/S0I40-6736(62)90729-8

28 Stewart WK, Mackenzie LA, Walker WF et al. Cardiac arrest trolley. Scott Med J 1969; 14:180-3.

\section{SENIOR FELLOWS' CLUB PRIZE}

The Senior Fellows' Club Prize for 201 I has been won by Dr A D McCallum, for his paper entitled 'Non-tuberculous mycobacterial infections in the Scottish Borders: identification, management and treatment outcomes - a retrospective review'. This can be seen in our December $201 \mathrm{I}$ issue at:

\section{http://www.rcpe.ac.uk/journal/issue/journal_4I_4/faccenda.pdf}

A prize of $£ 200$ will be awarded to the first-named (or corresponding) author of an original research paper on a clinical topic, deemed by a panel of judges to be the best paper by a doctor-in-training (i.e. pre-consultant level) published in the The Journal of the Royal College of Physicians of Edinburgh in 2012. The best paper will be selected by a panel of judges, including a senior Fellow, an active clinician and a member of the editorial team.

Further details may be obtained from the Editorial Office, RCPE, 9 Queen Street, Edinburgh, EH2 IJQ, tel 0I3I 2473652 or email editorial@rcpe.ac.uk. 